\title{
Quality of service; A view at the food and beverage establishments of a municipality in southern Sonora
}

\section{Calidad del servicio; Una mirada a los establecimientos de alimentos y bebidas de un municipio del sur de Sonora}

BAEZ-PORTILLO, María Marysol†*, VALENZUELA-CADENA, Andrea Carolina, HERNÁNDEZPONCE, Oscar Ernesto and CÓRDOVA-CÁRDENAS, Gilberto Manuel

\author{
Instituto Tecnológico de Sonora
}

ID $1^{\text {st }}$ Author: María Marysol, Baez-Portillo / ORC ID: 0000-0003-1231-4106, Researcher ID Thomson: X-2795-2018, CVU CONACYT ID: 290042

ID $1^{\text {st }}$ Coauthor: Andrea Carolina, Valenzuela-Cadena / ORC ID: 0000-0003-0860-2009, CVU CONACYT ID: 10140001

ID $2^{\text {nd }}$ Coauthor: Oscar Ernesto, Hernández-Ponce / ORC ID: 0000-0001-7169-8854, Researcher ID Thomson: X-22192018, CVU CONACYT ID: 284745

ID $3^{\text {rd }}$ Coauthor: Gilberto Manuel, Córdova-Cárdenas / ORC ID: 0000-0001-7169-8854, Researcher ID Thomson: X2219-2018, CVU CONACYT ID: 284745

DOI: $10.35429 / J E S .2019 .4 .3 .1 .10$

Received January 11, 2019; Accepted June 03, 2019

\begin{abstract}
The main objective of the investigation was to determine the level of quality of the service provided in the food and beverage establishments of Huatabampo Sonora. The methodology used in this research work has a quantitative approach and is descriptive non-experimental crosssection. Therefore, a documentary investigation was carried out to give theoretical support to the selected instrument. He multidimensional quantitative model called Dineserv, developed by Stevens, Knutson and Patton, (1995) cited by Guzmán and Cárcamo (2014), derived from the Servqual or Service Quality methodology of the authors Parasuraman was used to perform the service quality assessment, Zeithaml and Berry (1985). The results showed that the food and beverage establishments evaluated have a high level of service quality. To mention other results you can say that the contingency tables showed no significant differences in the age and gender of the subject in relation to the perception of service quality. Finally, it is observed that there is a significant positive correlation between the dimensions.
\end{abstract}

Quality, Service, Restaurants

\begin{abstract}
Resumen
El objetivo de la investigación fue determinar el nivel de calidad del servicio brindado en los establecimientos de alimentos y bebidas de Huatabampo Sonora. La metodología utilizada en este trabajo investigativo posee un enfoque cuantitativo y es de corte no experimental transversal descriptivo. Para ello se realizó una investigación documental para dar sustento teórico al instrumento seleccionado. Para realizar la evaluación de la calidad del servicio se utilizó el modelo cuantitativo multidimensional denominado Dineserv, desarrollado por Stevens, Knutson y Patton, (1995) citado por Guzmán y Cárcamo (2014), derivado de la metodología Servqual o Service Quality de los autores Parasuraman, Zeithaml y Berry (1985). Los resultados arrojados manifestaron que los establecimientos de alimentos y bebidas evaluados poseen un nivel de calidad en el servicio alto. Por mencionar otros resultados se puede decir que las tablas de contingencia mostraron no haber diferencias significativas en la edad y género del sujeto con relación a la percepción de la calidad en el servicio. Finalmente se observa que existe una correlación positiva significativa entre las dimensiones.
\end{abstract}

Calidad, Servicio, Restaurantes

Citation: BAEZ-PORTILLO, María Marysol, VALENZUELA-CADENA, Andrea Carolina, HERNÁNDEZ-PONCE, Oscar Ernesto and CÓRDOVA-CÁRDENAS, Gilberto Manuel. Quality of service; A view at the food and beverage establishments of a municipality in southern Sonora. Journal-Economic Systems. 2019. 3-4: 1-10

\footnotetext{
* Correspondence to Author (email: marysolbaez79@gmail.com)

$\dagger$ Researcher contributing as first author.
} 


\section{Introduction}

The restaurant industry is one of the main economic sectors of Mexico. According to data from the National Chamber of the Restaurant of Restaurants and Spiced Food (CANIRAC), the restaurant industry in the country registered a growth of 2.8 percent during 2017, indicating that the industry is becoming stronger. However, the number of establishments that opens each year exceeds the demand behavior of this type of services.

Analyzing some statistics, it is mentioned that Forbes magazine in 2016 refers to the fact that there are more than 450,000 food and beverage establishments in Mexico, which represent more than 1,000 million pesos in sales.

According to the National Institute of Statistics and Geography (INEGI), there are currently 451,854 food and beverage preparation establishments in Mexico, and it is estimated that they have more than 1.5 million people employed. It is for this reason that it is necessary to mention that the restaurant industry is the second largest employer at the national level and the first in self-employment.

The activity of this type of companies is related to the food environment, same as Navarro \& Vélez (2019) mention that it refers to the food available to people around them as they progress in their daily life and quality, safety, price, convenience, labeling and nutritional promotion of these foods.

Starting from the quality of the products and services offered in food and beverage establishments from the academic and business point of view, current trends are aimed at generating a high level of quality in services, which is synonymous with competitiveness and positioning in the market. That is why today, we work to seek quality in service, thus achieving differentiation between competitors, greater productivity in the service process, increasing customer satisfaction, increasing the morale of the employees, the improvement of their administration and better labor relations; encompassing these aspects as a competitive advantage in the market (Fraser, Watanabe, \& Hvolby, 2013) cited by Sánchez G \& Sánchez (2016).
The perception of the value generated by a service is relative to each customer experience due to certain implications, the perception of quality is particular to each client, which is why the quality of a service must be aspired, either through the attempt to match or exceed customer expectations or by controlling them to reduce the gap between perceived and expected value. Based on the aforementioned, the following question arises: What will be the level of service quality in food and beverage establishments in the municipality of Huatabampo?

In that sense, the objective of this research is to evaluate the quality of the service in food and beverage establishments through the DINESERV instrument, in order to determine the level of quality in the service perceived by the diners in the municipality of Huatabampo, Sonora.

\section{Method Description}

The present investigation is of quantitative type, based on the statements of Hernández, Fernández and Baptista, (2010) since its main characteristics show that numerical data is processed and analyzed that will support the determination of a result. On the other hand, it is considered that the research is of a nonexperimental transversal type, since in accordance with the studies of the authors in question, a non-experimental investigation intends to observe the phenomena as they occur in their natural environment to subsequently analyze them without alter any variable.

Finally, it also has a descriptive approach, since according to Hernández, Fernández and Baptista (2014) a descriptive investigation evaluates or measures various aspects of the phenomenon to be investigated. As mentioned earlier, this study aims to assess the level of satisfaction in terms of the quality of service perceived in various food and beverage establishments in the municipality of Huatabampo, Sonora. For the realization of this research project, the guests of various food and beverage establishments located in the municipality of Huatabampo were taken as subjects of study, since the perceptions regarding the quality of the company's service are evaluations carried out exclusively by the customers. 
The population was made up of diners who attended the food and beverage establishments of the municipality of Huatabampo in the month of May 2019, selecting a non-probabilistic sample of 100 clients. It should be mentioned that the sample was a fee for convenience, known as a nonprobabilistic sampling technique where the participants were selected given the convenient accessibility and proximity of the subjects to the researcher.

The multidimensional quantitative model called Dineserv, developed by Stevens, Knutson and Patton, (1995) cited by Guzmán and Cárcamo (2014), derived from the Servqual or Service Quality methodology of the authors Parasuraman, Zeithaml, was used to perform the quality assessment. and Berry (1985).

The instrument consists of 29 items grouped into five dimensions: Tangible aspects, reliability, response, guarantees and empathy. The reagents that are evaluated in the instrument, together with the corresponding reagent number in it, are mentioned by dimension.

Tangible aspects: 1) it has exterior facilities and a visually attractive parking area. 2) It has a visually attractive dining area. 3) It has staff that looks clean, well-cared for and properly dressed. 4) It has a decoration according to its image and price level. 5) It has a menu letter that is easy to read. 6) It has a visually appealing menu that reflects the image of the restaurant. 7) It has a dining area that is comfortable and makes it easy to move around it. 8) It has bathrooms that are very clean. 9) It has dining areas that are very clean. 10) has comfortable seating in the dining room area.

Reliability: 11) serves the food / drink at the promised time. 12) Quickly correct everything that is wrong. 13) It is reliable and consistent. 14) Provide the customer with the precise billing / account. 15) Serve meals / drinks exactly as ordered.

Answer: 16) During the busiest hours, it has employees that help each other to maintain speed and quality of service. 17) Provide timely and fast service. 18) provides extra effort to handle your special requests.
Guarantees: 19) you have employees who can answer your questions completely. 20) It makes you feel comfortable and confident in your dealings with the staff. 21) has staff that is capable and willing to give you information on the items of the menu, ingredients and methods of preparation of the dishes / drinks. 22) Makes you feel personally safe regarding the hygienic preparation of food. 23) It has staff that seem well trained, competent and experienced. 24) seems to give his employees the support so they can do their job well.

Empathy: 25) has employees who are sensitive to their needs and wants, instead of following standard policies and procedures. 26) It makes you feel special as a client by providing personalized attention. 27) anticipate your individual needs and desires. 28) has employees who are understanding and always check if something is wrong. 29) seems to always take customer interests into account.

In Table 1 you can see each of the dimensions of the instrument used to evaluate the quality of service perceived by diners, together with a brief description of them and the reagents that are part of it.

\begin{tabular}{|c|c|c|}
\hline Dimension & Definition & Reagents \\
\hline $\begin{array}{l}\text { Tangible } \\
\text { aspects }\end{array}$ & $\begin{array}{l}\text { Related to the appearance of physical } \\
\text { facilities, equipment, personnel and } \\
\text { communication material. These are the } \\
\text { physical aspects that the client perceives, } \\
\text { such as the physical design of the restaurant, } \\
\text { the appearance of the contact staff and the } \\
\text { cleanliness of the place. }\end{array}$ & $\begin{array}{l}\text { From } 1 \text { to } \\
10\end{array}$ \\
\hline Reliability & $\begin{array}{l}\text { It involves issues related to the freshness and } \\
\text { temperature of food, accurate billing and } \\
\text { receiving, specifically, the food and drinks } \\
\text { ordered by the customer. }\end{array}$ & $\begin{array}{l}\text { From } 11 \\
\text { to } 15\end{array}$ \\
\hline Reply & $\begin{array}{l}\text { (before the demands of the client) Regarding } \\
\text { personal assistance with the menu-menu of } \\
\text { food and / or drinks or the appropriate and } \\
\text { quick response regarding the needs and } \\
\text { requests of the customers. }\end{array}$ & $\begin{array}{l}\text { From } 16 \\
\text { to } 18\end{array}$ \\
\hline Guarantee & $\begin{array}{l}\text { (assurance or compliance) Understood as } \\
\text { that restaurant customers must be able to rely } \\
\text { on the recommendations of the contact } \\
\text { personnel, be sure that food and / or drinks } \\
\text { are prepared without any contamination, as } \\
\text { well as being able to express any concern, } \\
\text { concern or ask without fear. }\end{array}$ & $\begin{array}{l}\text { From } 19 \\
\text { to } 24\end{array}$ \\
\hline Empathy & $\begin{array}{l}\text { Concerning the ability to provide } \\
\text { personalized attention to customers through } \\
\text { the provision of needs (dietary, special) or by } \\
\text { the willingness of staff to be comprehensive } \\
\text { towards the needs of customers. }\end{array}$ & $\begin{array}{l}\text { From } 25 \\
\text { to } 29\end{array}$ \\
\hline
\end{tabular}

Table 1 Dineserv instrument dimensions. Own elaboration based on Stevens, et al (1995) cited by Guzmán and Cárcamo (2014). 
For the response options, a Likert scale of five options was used, giving the option to answer with values from 1 to 5 , where 1 represents the minimum value and 5 the maximum value. The instrument includes only positive reagents, so it was not necessary to reverse any scale statement.

According to Arias (2014) validity is the degree to which the instrument appreciates or measures what it intends. For the purpose of this investigation, the variable that is intended to be measured is the quality of the service.

The instrument was tested for validity and reliability, in its application, a posteriori, in relation to the validity of the instrument, the concurrent validity test was applied, through contrasted groups, through the Chi Square test, with values whose significance bilateral asymptotic was less than 0.05, where all 29 reagents met the frequency distribution requirement.

The reliability of the instrument was also determined through the internal consistency of the scale, using the Cronbach alpha coefficient from which a value of 0.978 was obtained; a value greater than the acceptable reference value of 0.7 for Cronbach's alpha, according to Kerlinger and Lee, (2008); Campo and Oviedo, (2008); De la Ossa, Martínez, Herazo y Campo, (2009); Prieto y Delgado, (2010); Miranda J.B, Miranda J. F. \& Rodulfo, (2010). It should be noted that According to Kerlinger \& Lee, (2008); Campo \& Oviedo, (2008) Cronbach's alpha index is the most general reliability coefficient

For the interpretation of results, four levels of service quality were determined: very high, high, low and very low, evenly distributing the difference between the maximum and minimum response value (maximum value: 5 and minimum value: 1 ).

\section{Theoretical framework}

According to Zeithaml, Parasuraman \& Berry (1988), the perceived quality of a service can be defined as the degree to which a company satisfactorily fulfills its purpose.
Thus, it is noted that the perception of quality in the service that is formulated in the customers of a restaurant will be the result of the evaluation of their culinary experience and the expected service (service expectations). In that sense, the authors propose a model for measuring the quality of services called SERVQUAL that consists of five dimensions: tangible aspects, reliability, efficiency of response to the request, assurance of what is offered and empathy with the client.

However, Stevens, Knutson and Patton, (1995) cited by Guzmán and Cárcamo (2014) adapted the Servqual to the restaurant industry, presenting the Dineserv instrument, a multidimensional quantitative model that consists of the same dimensions as the Servqual, but conceptualized according to sectoral differences.

In the case of Dineserv; It is a model that was adapted to be used to determine how customers perceive the quality of service in restaurants for continuous advice on customer perceptions of restaurant quality. The perceived service quality is a function among three independent variables (regulatory expectations, predictive expectations and current quality service) where if customers have a low consumer expectation, the higher the perception of the current service. The tool uses the same dimensions to SERVQUAL (tangibility, reliability, responsiveness, security and empathy), the authors only made a modification to the restaurant industry approach. (Aguirre, 2014)

A study called The evaluation of service quality: case study " Restaurant Familiar los Fresnos " conducted by Guzmán and Cárcamo in 2014 where they applied the level of quality of service expected and perceived (expectations and perceptions) was evaluated Based on 35 attributes. The first 29 attributes were adapted from the study of Stevens, Knutson and Patton, (1995) cited by Guzmán and Cárcamo (2014), that is, of the Dineserv and Servqual model, which represent the attributes corresponding to the five dimensions of quality in the restaurant services (Tangible aspects or elements, Reliability, Response, Guarantees and Empathy). 
The remaining six attributes were selected from the research carried out by Andaleeb \& Conway (2006) cited by Guzmán and Cárcamo (2014), which represent two important dimensions related to quality in restaurant services corresponding to the variables of Price and Total Satisfaction of the service received.

In this research study the following results were obtained. In the Tangible aspects it was obtained that it includes most of the reagents initially assigned to the dimensions of clean dining room, outdoor facilities, parking area shown and the dining area visually attractive. In addition to a decoration according to the image, price level that manages the restaurant, the staff with good presentation and the clean and comfortable bathroom area. The visually appealing menu-menu is placed in the seventh component as a minor element.

This second factor measured the reliability where $50 \%$ of the attributes were concentrated as the most preferred by the customers: serving food and drinks in the promised time, the consistent and reliable service when serving food and / or drinks and Finally it refers to the item always serving food and / or drinks exactly as ordered. The degree of response was the factor that stood out most among the surveyed customers was the corresponding element to always provide a timely and fast service and always seeks to give extra effort to handle their special requests.

The guarantee factor stood out for the preferences that the respondents showed the following elements: it has personnel capable and willing to give information on elements of the menu-menu, it makes the diner feel safe by providing hygiene in food and drinks and finally the corresponding element to whether the business management provides support to its employees so that they perform well.

Regarding empathy, the following aspects were mostly valued by customers: waiters are sensitive to individual needs, customer service is personalized, there is anticipation of individual customer needs, staff is comprehensive and always Check if something is wrong and there is real sincerity on the part of the waiters when serving their customers.
Finally, in the area of satisfaction, only the element concerning whether diners are completely satisfied with the culinary experience lived in the restaurant stood out, without regard to the other elements that make up this dimension.

The attributes of the dimensions with the greatest statistically significant differences represent transcendental deficiencies that require significant attention by the management of Los Fresnos, in terms of making continuous improvement efforts.

Through the modified Dineserv / Servqual questionnaire, restaurant managers and / or administrators can obtain useful information on the perception of the quality of services by customers, in addition to identifying problem areas and seeking improvements. The measurement instrument proposed in this investigation also provides a quantifiable measure regarding what customers or diners expect from a restaurant and its services.

\section{Results}

In this research work the quality of service in food and beverage establishments in the municipality of Huatabampo, Sonora was studied. The results of the investigation include a statistical analysis as well as the interpretation of the results. It is necessary to say that the percentage distribution according to the sex of the respondent, was 52 percent of the male sex and 48 percent of the female, which can be seen in Figure 1.

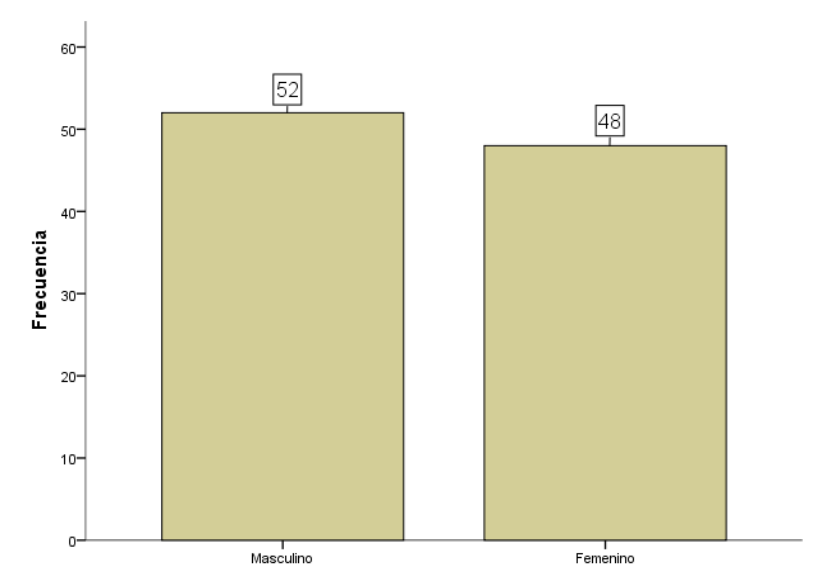

Graphic 1 Percentage distribution Own Elaboration (2019) 
In Graphic 2 it is observed that 87 percent of the guests surveyed had previously visited the restaurant on one or more occasions. While for 13 percent it was the first time they came to the establishment.

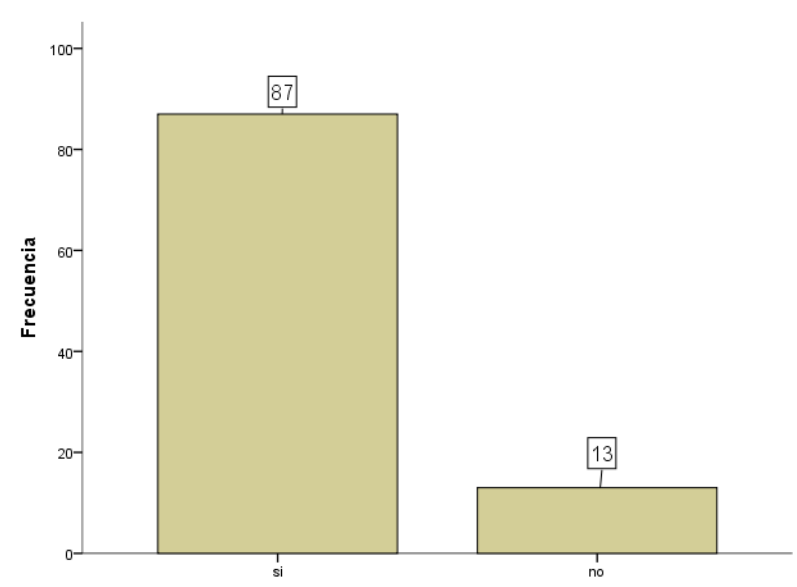

Graphic 2 Previous visits to the restaurant Own Elaboration (2019)

Graphic 3 shows the occupations manifested by the subjects, with the students being 29 percent. On the other hand, it is observed that 19 percent of the respondents were professionals and 18 percent were employed. Only 13 percent of diners commented working in the area of teaching.

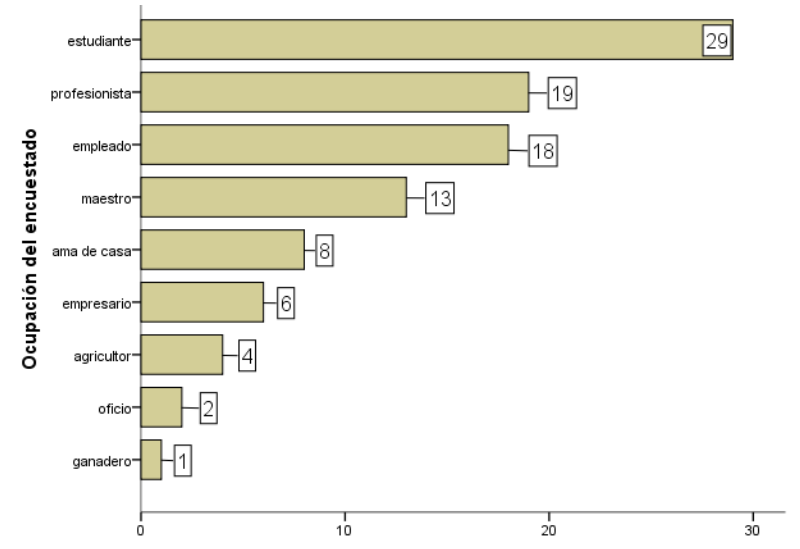

Graphic 3 Respondent's occupation Own Elaboration (2019)

Below are a series of contingency tables where sociodemographic data were compared with the dimensions of the instrument, or the scale in general. Thus, as in Table 2, it is observed that male respondents represented by 46 percent, mentioned perceiving a very high level of service quality, while the female gender is represented by 36 percent.

\begin{tabular}{|l|l|r|r|r|r|r|}
\cline { 3 - 7 } \multicolumn{2}{c|}{} & \multicolumn{4}{c|}{ Quality level in the service } & \multirow{2}{*}{ Total } \\
\cline { 3 - 7 } \multicolumn{2}{c|}{$\begin{array}{c}\text { Very } \\
\text { low }\end{array}$} & Low & High & $\begin{array}{c}\text { Very } \\
\text { high }\end{array}$ & \\
\hline $\begin{array}{l}\text { Respondent } \\
\text { Gender }\end{array}$ & Male & 2 & 0 & 4 & 46 & 52 \\
\cline { 2 - 7 } & Female & 2 & 2 & 8 & 36 & 48 \\
\hline \multicolumn{2}{|l|}{ Total } & 4 & 2 & 12 & 82 & 100 \\
\hline
\end{tabular}

Table 2 Service quality level by gender Own Elaboration (2019)

Table 3 shows that 87 percent of the respondents visited the restaurant previously, of which 71 percent mentioned perceiving a very high level of service quality, only 5 percent expressed a level of quality in the Very low and low service, which confirms the reason why diners have returned to visit food and beverage establishments.

\begin{tabular}{|c|c|c|c|c|c|c|}
\hline & \multicolumn{4}{|c|}{ Quality level in the service } & \multirow[t]{2}{*}{ Total } \\
\hline & & $\begin{array}{l}\text { Very } \\
\text { low }\end{array}$ & Low & High & $\begin{array}{l}\text { Very } \\
\text { high }\end{array}$ & \\
\hline \multirow{2}{*}{$\begin{array}{l}\text { Prior visits to the } \\
\text { restaurant by } \\
\text { respondent }\end{array}$} & Yes & 3 & 2 & 11 & 71 & 87 \\
\hline & No & 1 & 0 & 1 & 11 & 13 \\
\hline \multicolumn{2}{|l|}{ Total } & 4 & 2 & 12 & 82 & 100 \\
\hline
\end{tabular}

Table 3 Contingency table of the previous visits of the respondent in relation to the level of quality of the perceived service

Own Elaboration (2019)

Table 4 shows that 64 percent of respondents who visited the restaurant are from Huatabampo, which is logical since it is the place where the restaurants under study are located. Of the previous percentage, 94 percent say they perceive a level of service quality between Very high and High. Secondly the restaurants are visited by people who come from Navojoa, Etchojoa and Bacobampo correspondingly.

\begin{tabular}{|c|c|c|c|c|c|c|}
\hline & \multicolumn{4}{|c|}{ Quality level in the service } & \multirow[t]{2}{*}{ Total } \\
\hline & & $\begin{array}{l}\text { Very } \\
\text { low }\end{array}$ & Low & High & $\begin{array}{l}\text { Very } \\
\text { high }\end{array}$ & \\
\hline \multirow{7}{*}{$\begin{array}{l}\text { Hometown of } \\
\text { the respondent }\end{array}$} & Navojoa & 0 & 0 & 1 & 15 & 16 \\
\hline & Huatabampo & 2 & 2 & 6 & 54 & 64 \\
\hline & Etchojoa & 0 & 0 & 5 & 4 & 9 \\
\hline & Bacobampo & 0 & 0 & 0 & 7 & 7 \\
\hline & Moroncárit & 1 & 0 & 0 & 0 & 1 \\
\hline & San Antonio & 1 & 0 & 0 & 1 & 2 \\
\hline & Hermosillo & 0 & 0 & 0 & 1 & 1 \\
\hline \multicolumn{2}{|l|}{ Total } & 4 & 2 & 12 & 82 & 100 \\
\hline
\end{tabular}

Table 4 Contingency table of the place of origin of the subject in relation to the level of quality of the perceived service

Own Elaboration (2019)

Table 5 shows the dimensions of the scale and its correlation between them. 
It is observed that the dimension of Tangible Aspects has a high (significant) average correlation with the Reliability dimension.

That is, 8 out of 10 subjects who perceive that the facilities of the establishment are attractive, that the menu shown in the menu is visually attractive and easy to read and that the appearance of their staff looks clean and properly dressed, they feel reliable Upon receiving the service, that is, they also perceive that the food and beverages are served as ordered, that the errors on the part of the company will be corrected immediately and that the billing of the service received will be given correctly and accurately.

In itself ... the greater the perception of the quality of tangible aspects, the greater the reliability towards the company.

Similarly, there is a positive correlation between the Reliability and Guarantee dimension, that is, 80 percent of the respondents who perceive that the product and service they receive is as promised, they also receive a guarantee on the product and service received. , that is to say, the client has the guarantee that the employee is competent and will answer their doubts, they also perceive that the employee makes the diner feel personally safe in relation to the hygienic preparation of food and drinks.

Finally, in Table 5 it is observed that there is a significant correlation between the Guarantee and Empathy dimension. This means that 8 out of 10 subjects surveyed who perceive the guarantor that their doubts or problems will be resolved by the employees and that they feel confident with the treatment they receive, also perceive that the employees are sensitive to their wants and needs and that make you feel special as a customer.

In the same way, customers perceive that the company has employees who are understanding and always verify if something is wrong and that the organization seems to always take into account the interests of customers. Which makes perceive the client that receives a personalized and efficient service.

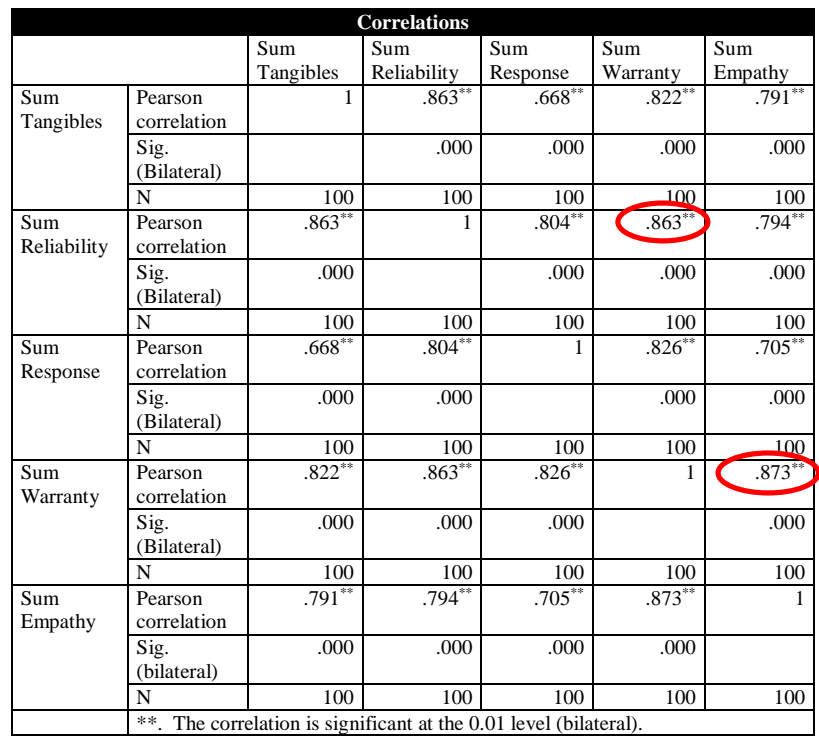

Table 5 Table of correlations between dimensions Own Elaboration (2019)

Below are the levels of quality in the service by dimension. In Graphic 4 you can see the level of quality in the service perceived by the subjects evaluated according to the dimension of tangible aspects. In that sense, 94 percent perceive a high and very high level of service quality.

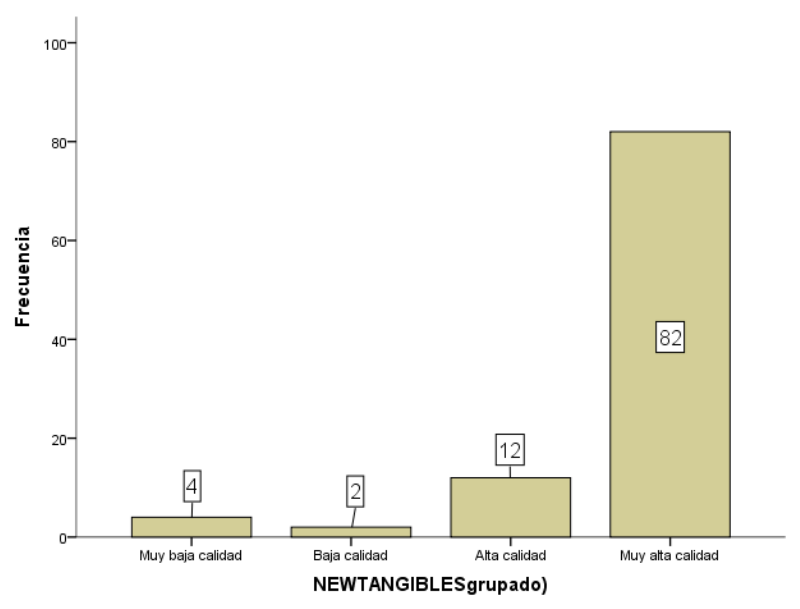

Graphic 4 Quality level in the service of the dimension of tangible aspects

Own Elaboration (2019)

In Graphic 5 you can see the level of quality in the service perceived by the subjects evaluated according to the Reliability dimension, where 93 percent perceive a high and very high level of service quality. 


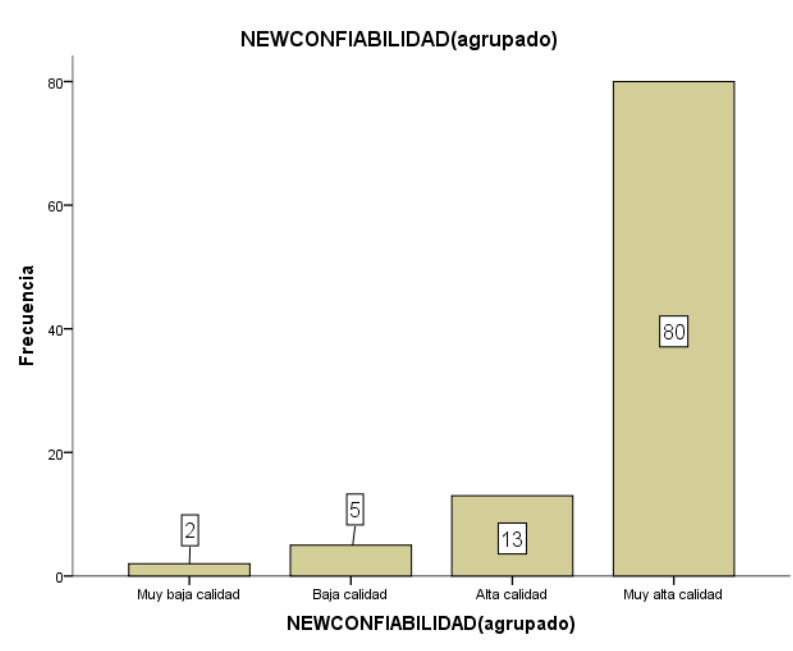

Graphic 5. Quality level in the service of the Reliability dimension

Own Elaboration (2019)

In Graphic 6 you can see the level of service quality perceived by the subjects evaluated according to the Response dimension, where 96 percent perceive a high and very high level of service quality.

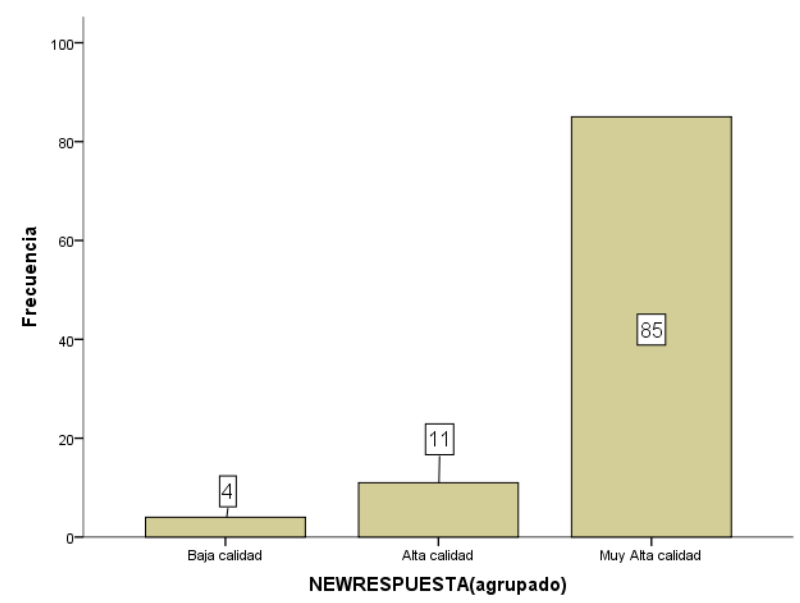

Graphic 6 Quality level in the service of the Response dimension

Own Elaboration (2019)

In Graphic 7 you can see the level of service quality perceived by the subjects evaluated according to the Guarantees dimension, where 99 percent perceive a high and very high level of service quality.

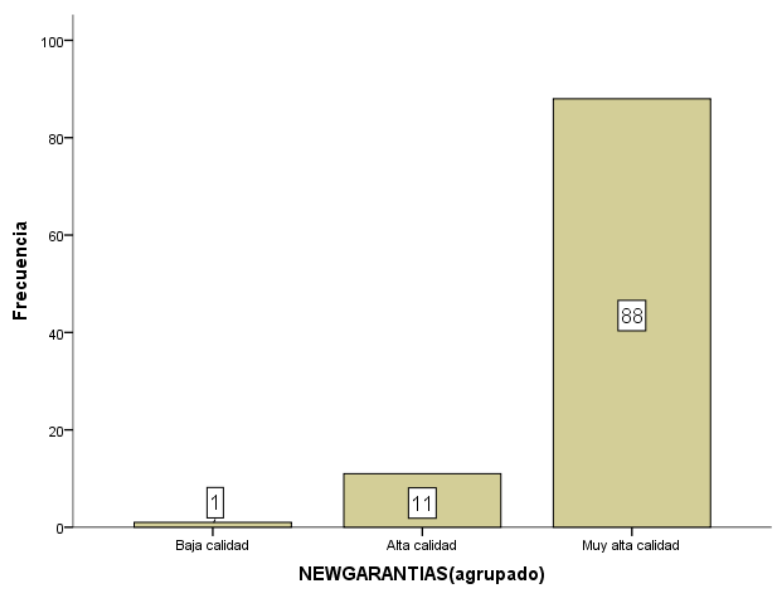

Graphic 7 Quality level in the service of the Guarantees dimension

Own Elaboration (2019)

In Graphic 8 you can see the level of service quality perceived by the subjects evaluated according to the Empathy dimension, where 98 percent perceive a high and very high level of service quality.

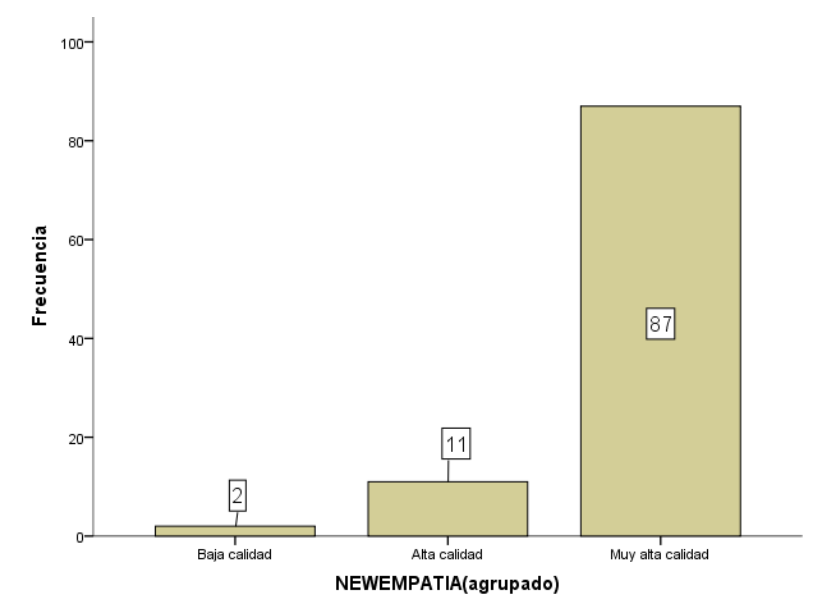

Graphic 8. Quality level in the service of the Empathy dimension

Own elaboration (2019)

In Graphic 9 you can see the level of quality in the service perceived by the subjects evaluated according to the total dimensions, where 94 percent perceive a high and very high level of service quality. 


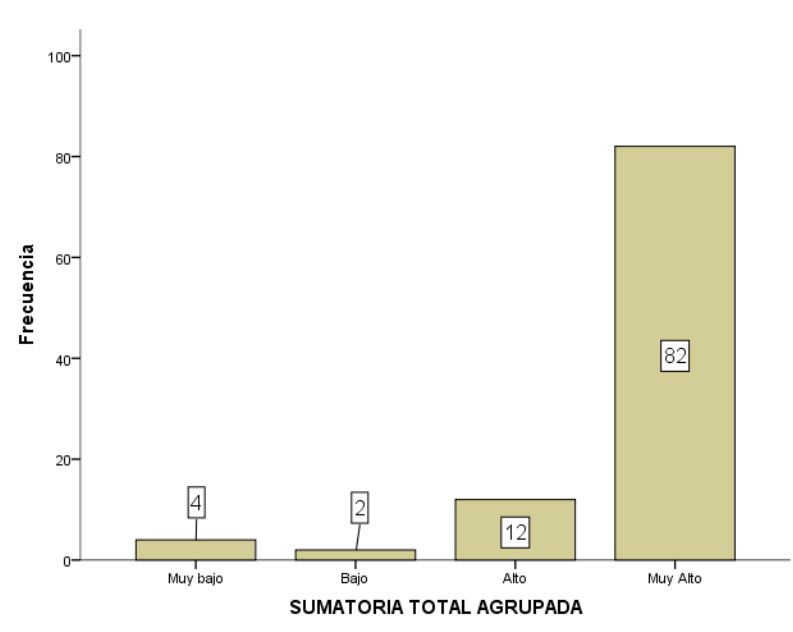

Graphic 9 Quality level in total dimensions service Own Elaboration (2019)

\section{Conclusions}

The objective of the investigation itself was fulfilled, which consisted in determining the level of service quality of the food and beverage establishments of the municipality of Huatabampo, Sonora, which $90 \%$ of the subjects surveyed consider having a high level of quality in the service. Likewise, 8 out of 10 cases the diner believes that the company gives a quick and efficient response to their needs and 7 out of 10 customers feel that the company is empathic with them.

It is urged to deepen the level of analysis of the results of this research by conducting studies of the dimensions of the instrument, as well as the correlations with the sex of the respondent, the place of origin, among others. Similarly, it would be interesting to investigate the influence of the level of quality in the service in relation to another variable, such as worker productivity, organizational climate, among others.

Finally, it is recommended to conduct workshops for employees with the aim of improving their performance within the company. Conduct an investigation that analyzes not only customer perceptions but expectations, to analyze the gap between them.

\section{References}

Aguirre, A.C. (2014). Metodología y Herramienta para la Medición de Percepción en los Atributos de Calidad entre el Cliente y el Empleado de un Restaurante. (Tesis inédita de maestría). Instituto Tecnológico y de Estudios Superiores de Monterrey. México.

Arias, F. (2014). Metodología de la investigación. (Séptima edición). México: Trillas.

Campo, A. y Oviedo, H. (2008) Propiedades psicométricas de una escala: la consistencia interna. Revista de Saludo Pública. Vol. 10 (5). 831-839.

De la Ossa, S., Martínez, Y., Herazo, E. y Campo, A. (2009). Estudio de la consistencia interna y estructura factorial de tres versiones de la escala Zung para ansiedad. Revista Colombia Médica. Vol 40 (1) 71-77.

Forbes México. (2016). Sector restaurantero genera 1, 000 millones de MDP en ventas. Recuperado de https://www.forbes.com.mx/sectorrestaurantero-genera-1000-mdp-ventas/

Guzmán, A. \& Cárcamo, M. L. (2014). La evaluación de la calidad en el servicio: caso de estudio "Restaurant Familiar Los Fresnos". Revista Acta Universitaria. Vol. 24 (3), 35-49.

Hernández, R., Fernández, C. \& Baptista, M. P. (2010). Metodología de la investigación. México. (Quinta edición). México: McGraw Hill.

Hernández, R., Fernández, C. \& Baptista, MP. (2014). Metodología de la investigación. (Sexta edición). México: McGraw Hill.

Instituto Nacional de Geografía y Estadística INEGI. (2009). Prontuario de información geográfica municipal de los Estados Unidos Mexicanos. Recuperado de http://www.beta.inegi.org.mx/contenidos/app/m exicocifras/datos_geograficos/26/26033.pdf

Instituto Nacional de Estadística y Geografía (INEGI). (2009). México en cifras, Huatabampo, Sonora. Recuperado de https://www.inegi.org.mx/app/areasgeograficas/ $? \mathrm{ag}=26 \#$ tabMCcollapse-Indicadores 
Kerlinger, F. y Lee, H. (2008). Investigación del comportamiento. Métodos de investigación en ciencias sociales. (Cuarta Edición). México: McGraw Hill.

Miranda, J. B., Miranda, J. F. y Rodulfo, J. (2010). Diseño, confiabilización y validación de un instrumento para medir el desempeño docente en la Maestría en Educación, Campo: Formación Red de Investigación Educativa en Sonora. Revista Electrónica de Investigación Educativa. Año II (5), 46-60.

Navarro, A.C., \& Vélez, M.I.O. (2019). Obesogenic Environment Case Study from a Food and Nutrition Security Perspective: Hermosillo City. International journal of environmental research and public health, 16 (3), 407.

Prieto, G. y Delgado, A. (2010). Fiabilidad y validez. Revista Papeles del Psicólogo. Vol. 31 (1) 67-74.

Sánchez Garcia, M. \& Sánchez Romero, M. (2016). Medición de la calidad en el servicio, como estrategia para la competitividad en las organizaciones. Ciencia Administrativa, ISSN: 1870-9427.

Zeithaml, V., Berry, L.L. \& Parasuraman, A. (1988). Communication and Control Processes in Delivery of Service Quality. Journal of Marketing, 52, 35-48. 